\title{
Oilseed brassica in India: Demand, supply, policy perspective and future potential ${ }^{\text {is }}$
}

\author{
R.S. Jat, V.V. Singh, Pankaj Sharma* and P.K. Rai \\ ICAR-Directorate of Rapeseed-Mustard Research, 321303 Bharatpur, India
}

Received 17 September 2018 - Accepted 21 January 2019

\begin{abstract}
India is the largest agrarian subcontinent supporting $26 \%$ world's agricultural population on $12 \%$ arable land. India is also the fifth largest vegetable oil economy accounting $7.4 \%$ oilseeds, $5.8 \%$ oils and $6.1 \%$ oil meal production, and $9.3 \%$ of edible oil consumption in the world. Oilseeds are the second most important agricultural economy in India next to cereals growing at a pace of $4.1 \%$ per annum in the last three decades. Oilseed brassica shares $23.5 \%$ area and $24.2 \%$ production of total oilseeds in the country. Despite being the third largest producer (11.3\%) of oilseed brassica after Canada and China in the world, India meets $57 \%$ of the domestic edible oil requirements through imports and ranked 7th largest importer of edible oils in the world. Oilseed brassica achieved significant growth in India in the past, however, the productivity levels are still low owing to large cultivation under rainfed situation, biotic and abiotic stresses, and resources crunch. It is also facing the challenges of low genotypic potential, climate change and price fluctuation. Though, it embraces the immense scope to increase the production in traditional and non-traditional areas in India with proper inputs, technological interventions, and suitable policy framework. This needs to develop strategies in a well-planned, targeted manner with multi-scientific inputs, policy interface and stable price systems to bring the desired growth in oilseeds brassica production, and to reduce the import of edible oils in the country.
\end{abstract}

Keywords: India / rapeseed / mustard / demand / supply / policy

Résumé - Moutarde en Inde : demande, offre, perspectives politiques et potentiel futur. L'Inde est le plus grand sous-continent agricole, avec $26 \%$ de la population agricole mondiale sur $12 \%$ de terres arables. L'Inde est également la cinquième économie dans le secteur des huiles végétales, avec $7,4 \%$ de graines oléagineuses, $5,8 \%$ d'huiles, $6,1 \%$ de tourteaux et $9,3 \%$ de la consommation d'huile alimentaire dans le monde. Les oléagineux constituent la deuxième économie agricole en Inde, après les céréales; ils ont crû à un rythme de $4,1 \%$ par an au cours des trois dernières décennies. Ils sont cultivés sur une superficie de 28,5 millions d'hectares avec une production annuelle de 32,9 millions de tonnes, impliquant respectivement 14,0 et 1,0 million d'habitants pour sa culture et son procès. Les graines oléagineuses représentent 3,0 \% du produit national brut et $10,0 \%$ de la valeur de tous les produits agricoles. La Mission technologique sur les oléagineux (Technology mission on oilseed [TMO]), une initiative du gouvernement indien visant à atteindre l'autosuffisance en matière de production d'oléagineux, a révolutionné la culture de la moutarde, qui représente actuellement $23,5 \%$ de la superficie et $24,2 \%$ de la production totale d'oléagineux dans le pays. Dans les statistiques mondiales sur les graines oléagineuses, l'Inde se classe au troisième rang des producteurs de moutarde après le Canada et la Chine, avec $11,3 \%$ de la production ( 71 millions de tonnes) et au septième rang des importateurs d'huile de moutarde (0,25 million de tonnes). Le secteur des oléagineux a connu une croissance importante dans le passé, soulignant le rôle des technologies et des politiques. Toutefois, l'Inde importe toujours environ $57 \%$ de ses besoins nationaux en huile alimentaire à partir de l'étranger. La moutarde, qui représente un quart de la production d'oléagineux, doit jouer un rôle essentiel dans la satisfaction des besoins nationaux en huile comestible, la baisse des importations d'huile comestible, la sécurité sanitaire et nutritionnelle, l'économie des agriculteurs et la réduction de l'empreinte carbone nationale. Il est nécessaire d'élaborer des stratégies bien planifiées et ciblées, avec des intrants scientifiques multiples, une interface politique et des systèmes de prix permettant de parvenir à la croissance souhaitée de l'économie nationale du secteur des oléagineux.

Mots clés : colza / moutarde / demande / offre / politique

\footnotetext{
Contribution to the Topical Issue "Rapeseed / Colza"

* Correspondence: pksvirus@gmail.com
} 
Table 1. The production and productivity of total oilseeds and oilseed brassica with compound annual growth rate (India).

\begin{tabular}{|c|c|c|c|c|c|c|c|c|c|c|}
\hline & & $\begin{array}{l}1950 \\
-1951\end{array}$ & $\begin{array}{l}1960 \\
-1961\end{array}$ & $\begin{array}{l}1970 \\
-1971\end{array}$ & $\begin{array}{l}1980 \\
-1981\end{array}$ & $\begin{array}{l}1990 \\
-1991\end{array}$ & $\begin{array}{l}2000 \\
-2001\end{array}$ & $\begin{array}{l}2010 \\
-2011\end{array}$ & $\begin{array}{l}2016 \\
-2017\end{array}$ & $\begin{array}{l}C A G R \\
(\%)\end{array}$ \\
\hline \multirow{2}{*}{ Total oilseeds } & Area (million ha) & 10.7 & 13.8 & 16.6 & 17.6 & 24.2 & 22.8 & 27.2 & 26.2 & 1.36 \\
\hline & Yield (kg/ha) & 481 & 507 & 579 & 532 & 771 & 810 & 1193 & 1225 & 1.43 \\
\hline \multirow[b]{2}{*}{ oilseed brassica } & Area (million ha) & 2.1 & 2.9 & 3.3 & 4.1 & 5.8 & 4.5 & 6.9 & 6.3 & 1.70 \\
\hline & Production (million tonnes) & 0.8 & 1.4 & 2.0 & 2.3 & 5.2 & 4.2 & 8.2 & 8.0 & 3.63 \\
\hline
\end{tabular}

Source: Agricultural statistics at a glance, Directorate of Economics and Statistics, Ministry of Agriculture, Govt. of India.

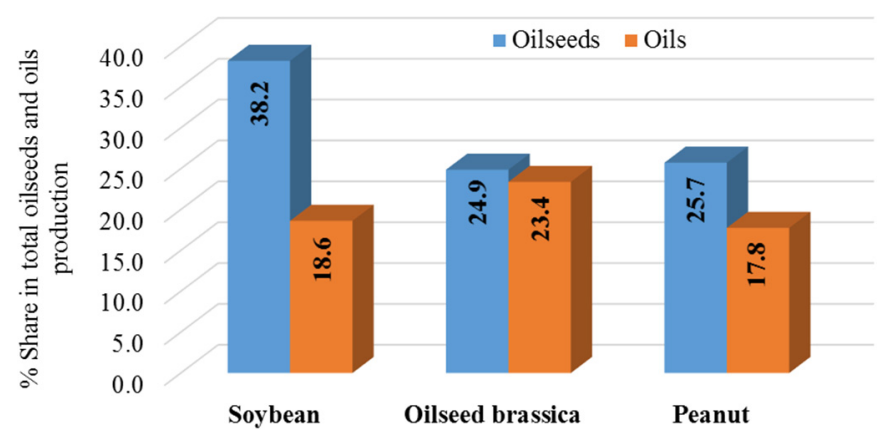

Fig. 1. The share of oilseed brassica in production of total oilseeds and edible oils in India.

\section{Socio-economic dimensions}

India is cultivating nine oilseed crops under the diverse agro-ecosystems, among which oilseed brassica stands second after soybean in terms of area $(24 \%)$ and production $(25 \%)$. The major oilseed brassica species cultivated in India are; Brassica juncea, B. rapa syn. B. campestris, B. napus and B. carinata (for edible oil), and B. oleracea and B. nigra (for seed condiments). Among these, B. juncea (L.) Czern, commonly referred as "Indian mustard" holding sizable contribution in terms of area and production of oilseeds, and edible oils. Oilseed brassica recorded quantum jump in production from a mere 0.76 million tonnes in 1950-1951 to 7.98 million tonnes in 2016-2017 (Table 1). Similarly, yield levels increased from $368 \mathrm{~kg} / \mathrm{ha}$ in $1950-1951$ to $1324 \mathrm{~kg} / \mathrm{ha}$ in the year $2016-2017$. The magnitude of increase in total oilseeds area, production and productivity in the country is $+144,+522$ and $+154 \%$ in 2016-2017, respectively over the base period of 1950-1951. During the same period, the oilseed brassica area, production, and productivity also increased by $+204,+950$ and $+260 \%$, respectively. The compound annual growth rate (CAGR) in area, production and yield levels of oilseed brassica is $+1.70 \%,+3.63 \%$ and $+1.96 \%$ during $2016-2017$ over 1950 1951 which is higher than total oilseeds $(+1.36 \%,+2.81 \%$ and $+1.43 \%$ ), respectively (Table 1 ).

Oilseed brassica share in total oilseeds production is second (25\%) after soybean (38\%), however, stand first $(23 \%)$ in edible oil production in the country (3 years average; 2014
2015, 2015-2016 and 2016-2017) (Fig. 1). It produces 2.2 million tonnes of edible oils and recorded $+12.5 \%$ annual growth rate during 2014-2015 to 2016-2017.

Worldwide, production of oilseed brassica is 72 million tonness from 35 million hectares acreage (3 years average; 2014, 2015 and 2016). Canada is the largest producer of oilseed brassica and holds major market followed by China. India stands third in terms of area and production after Canada and China, and fifth in terms of yield per hectare after Germany, France, Canada and China (Fig. 2).

Despite of significant progress achieved in the oilseeds production in India, vegetable oils import is $11.2 \%$ of the total world import worth of about 103.2 million US\$ in 2016-2017. The import has increased mainly due to increasing consumption of edible oils with the rising population and changing lifestyle of the people. During the last 10-11 years, the total consumption has been increased $(+163 \%)$ from 9.7 million tonnes in 2000-2001 to 25.4 million tonnes in 2016-2017 (Fig. 3). During the same period, the production of edible oils from all sources increased $(+84 \%)$ from 5.5 million tonnes in 2000-2001 to 10.1 million tonnes in 2016-2017. This gap between consumption and production is just met out through import which has increased $(+267 \%)$ from 4.2 million tonnes in 2000-2001 to 15.3 million tonnes in 2016-2017. Also, the per capita consumption of edible oils has increased $(+41 \%)$ from $13.3 \mathrm{~kg}$ in $2009-2010$ to $18.7 \mathrm{~kg} /$ head/year in $2016-2017$.

At present, vegetable oils hold $50 \%$ share (in terms of value) in the total import of the country and drain significant quantum of revenue to the foreign countries (Fig. 4). It is a stern apprehension to the national economy while fulfilling the domestic edible oils requirement simultaneously. India is mainly importing the refined edible oil from other countries against the negligible export. The situation will be more challenging with rising consumption up to 2030 with the projected population, and thereafter may increase at a decreasing rate with declining population growth rate.

The limited and steadily declining natural resources (land and water), and competition from agriculture and nonagricultural sector, jeopardized the scope to increase the acreage under oilseeds. In such a situation, increase in yield levels through translational scientific interventions is a conceivable alternative to increase the production and edible oil availability. There is a large gap between the world and India's oilseed brassica productivity of about $900 \mathrm{~kg} / \mathrm{ha}$ which 
R.S. Jat et al.: OCL 2019, 26, 8

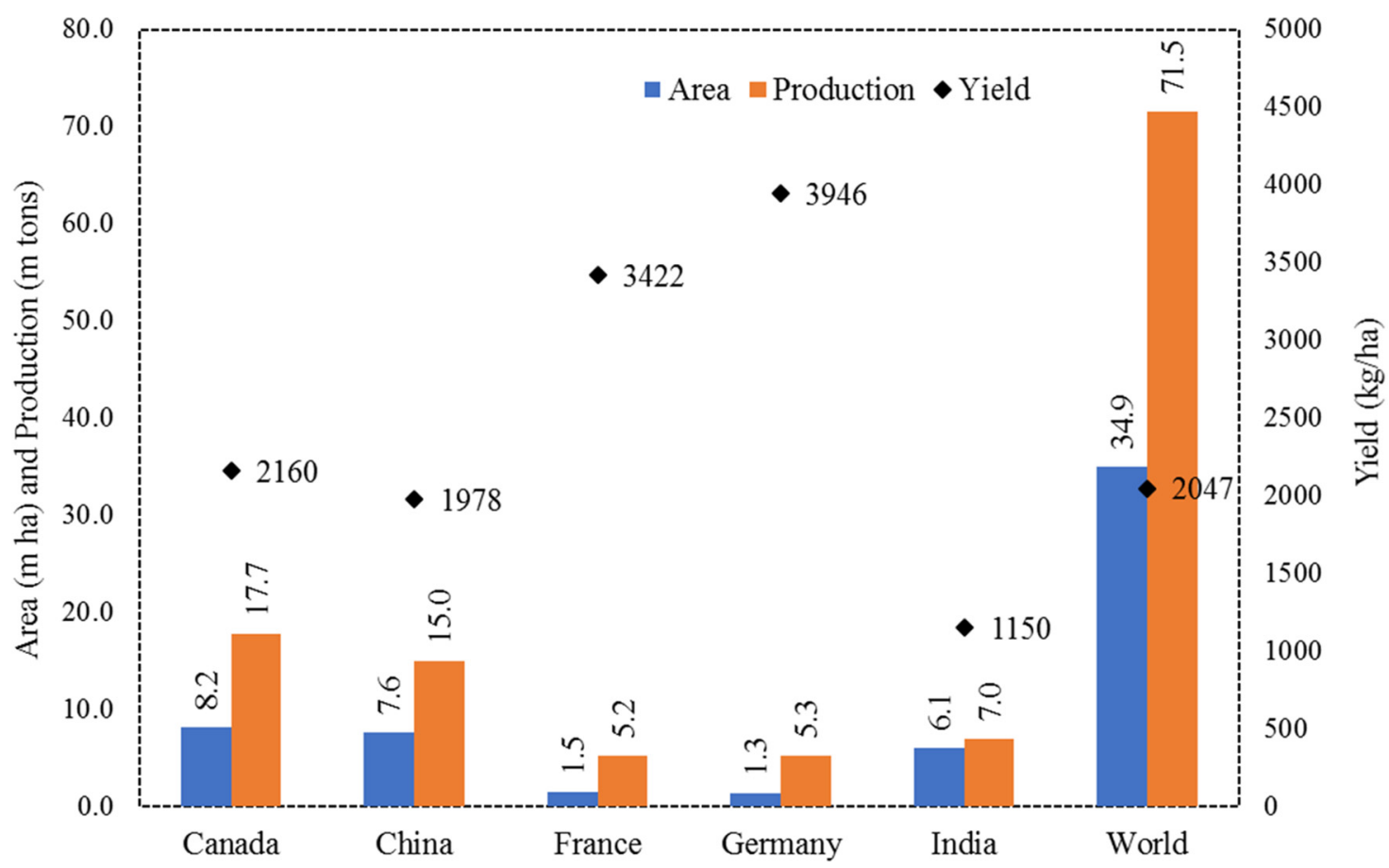

Fig. 2. Major oilseed brassica producing countries. Source: FAOSTAT, 2016.

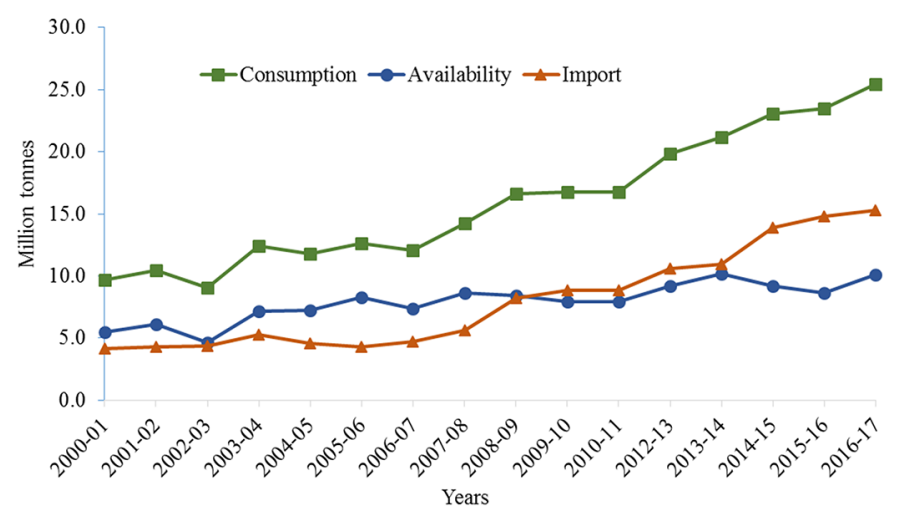

Fig. 3. Consumption, net domestic availability, and import of edible oils (India). Source: Directorate of Vanaspati, vegetable oils and fats.

needs to be bridged with the development of high yielding varieties and better resource management along with suitable policy backup.

The average productivity of oilseed brassica in India in the last 15 years $(2001-2016)$ is $1150 \mathrm{~kg} / \mathrm{ha}$ which is much lower than the world average productivity of $2047 \mathrm{~kg} / \mathrm{ha}$ (Fig. 5). The world oilseed brassica productivity is higher by $+178 \%$ than Indian productivity. The highest average yield per hectare (3 years average; 2014, 2015 and 2016) of rapeseed is in Germany $(3946 \mathrm{~kg} / \mathrm{ha})$ followed by France $(3422 \mathrm{~kg} / \mathrm{ha})$, Canada $(2160 \mathrm{~kg} / \mathrm{ha})$ and China $(1978 \mathrm{~kg} / \mathrm{ha})$. Though, the per day productivity (seed yield/crop duration) of oilseed brassica in India $(8.2 \mathrm{~kg} / \mathrm{ha} /$ day $)$ is at par with Australia $(8.6 \mathrm{~kg} / \mathrm{ha} /$ day $)$, Poland $(9.1 \mathrm{~kg} / \mathrm{ha} /$ day $)$, and China $(9 \mathrm{~kg} / \mathrm{ha} /$ day $)$ but much lower than Canada $(18 \mathrm{~kg} / \mathrm{ha} /$ day $)$, Germany $(12 \mathrm{~kg} / \mathrm{ha} /$ day $)$, and France $(10.4 \mathrm{~kg} / \mathrm{ha} /$ day $)$

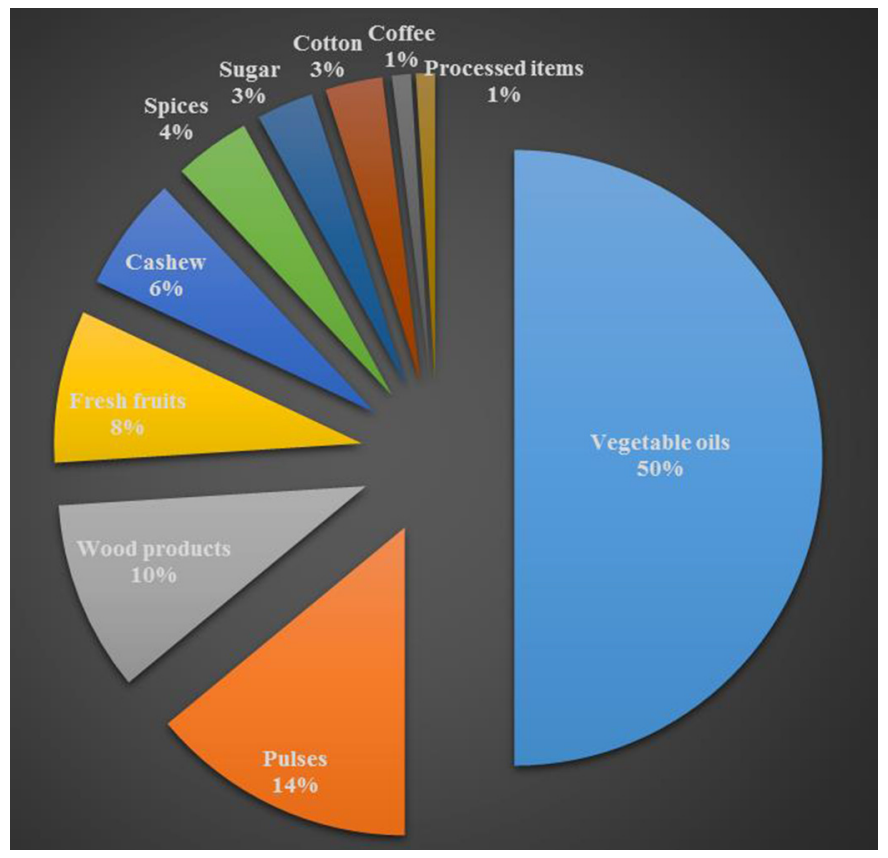

Fig. 4. Share of vegetable oils in total imports (in terms of value) in India.

(Table 2). The variation in per day productivity in European countries might be due to the longer crop duration where $90 \%$ period of a year is utilized by the rapeseed crop alone. The variation might also be due to the difference in cultivated species. The most popular cultivated species in India is $B$. juncea, whereas, in other countries, it is B. napus. The transcontinental yield variations are the point to ponder and to have technological insights to increase the edible oil and biofuel production in the future. 


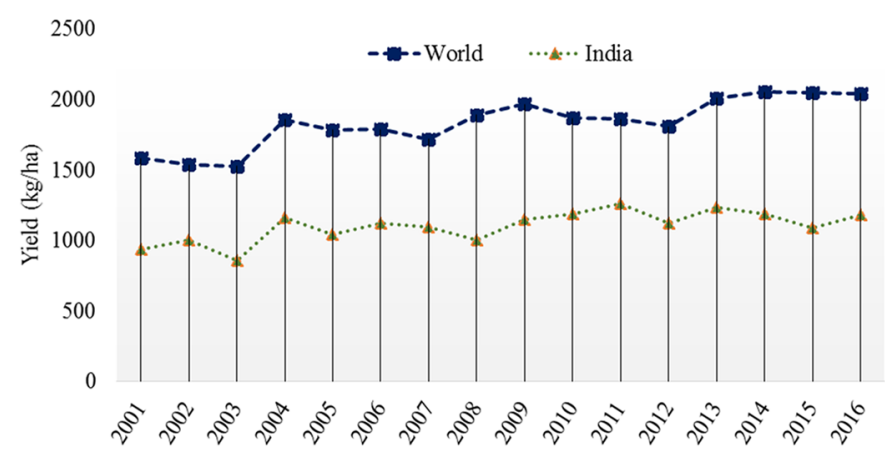

Fig. 5. Yield of oilseed brassica in the world and India. Source: FAOSTAT, 2016.

\subsection{Nutritional and health security}

Oilseeds have multifaceted uses and significant contribution in the much-hyped food security mission across the globe, both in terms of quantity and quality requirement. Vegetable oils must be part of a normal balanced and healthy diet as they are rich source of unsaturated fatty acids, essential fatty acids (linolenic and alpha-linolenic), vitamin E, and contain no dietary cholesterol. Indian mustard oil contains low amount of saturated fatty acids (palmitic acid and stearic acid) (8\%) and a high amount of monounsaturated fatty acids (oleic, eicosenoic and erucic acids) (70\%), and polyunsaturated fatty acids linoleic and linolenic acids (22\%) (Kumar, 2015). Indian mustard oil contains high amount of erucic acid (40-57\% of total fatty acids) which is not considered good for health, hence, efforts were made to develop varieties which contain erucic acid $<2 \%$ (Pusa karishma, Pusa mustard 21, Pusa mustard 22, RLC 1, Pusa mustard 24 and RLC 2, etc.). The mustard oil is high in omega-3, free from cholesterol and trans fats, and have a very low N-6 to N3 ratio) compared to other oils (Table 3 ).

Indian mustard oil is also frequently used in blends of vegetable oils (sunflower, soybean, corn, etc.) to improve the fatty acid profile mainly the omega- 3 fatty acid content and to give a better omega-3/omega- 6 fatty acid balance. With the rising trend in health and wellness internationally, the demand of mustard oil will rise further in direct consumption, valueadded products, and superfoods for specific health benefits.

\section{History and present status of the oilseed brassica development in India}

In past, brown mustard (B. rapa var. brown mustard) was the dominant oilseed brassica crop in India, however, today it is dominated by Indian mustard (B.juncea) ( $90 \%$ acreage). The different landraces of Brassica species have different ecological niches and developed the varieties as per their agroecological suitability. Indian mustard (B.juncea) is predominantly cultivated in western to central parts of North India and in some non-traditional areas of southern India. Yellow mustard (B. rapa var. yellow mustard) is finding a place in north-eastern India. Toria (B. rapa var. toria) is a short-duration crop cultivated largely in eastern India and in small patches in northern India as a catch crop. Taramira/rocket salad (Eruca sativa), a drought-tolerant species is grown in the drier parts of northwest India. Gobhi mustard (B.napus) and Ethopian
mustard/Karan rai (B. carinata) are the new emerging oilseed crops having a limited area under cultivation in northern India.

It is vital to look back through the CAGR per annum in area, production and yield of oilseeds as well as oilseed brassica during different periods of post-independence (1950 1951 to $1965-1966)$, pre-TMO (1966-1967 to 1985-1986), TMO (1986-1987 to 1995-1996) and post-TMO (1996-1997 to 2013-2014) to draw the future opportunities, constraints and strategies. The breakthrough in area, production and yield of oilseeds as well as oilseed brassica came after the launch of Technology Mission on Oilseeds (TMO) in the year 1986, a central government initiative to increase the production, reduce import and achieve self-sufficiency in edible oils in India. The period of TMO witnessed CAGR 3.37, 6.97 and $3.47 \%$ in oilseeds, and 5.82, 8.72 and $2.73 \%$ in oilseed brassica in terms of area, production and yield, respectively (Fig. 6). The growth was achieved mainly due to development of new varieties, technological advancements in production and protection, and policy interventions during this period. During post-TMO, there was a setback in the area, production and productivity which is a serious concern and underlines needs to revisit the policy outlines to increase the production of oilseeds as well as oil to attain self-sufficiency in edible oils.

In the era of globalization during 1994-1995, the Government of India took certain decisions and opened free trade under Open General License (OGL) and reduced the import duty on edible oils from 65 to $15 \%$ which resulted into heavy imports. This has not only drained money to foreign lands but also has had the cascading effect on domestic oil prices, and impacted Indian oilseed industry with a considerable disincentive to the oilseed farmers. Though, during the TMO period, there was effective implementation of minimum support price (MSP) through National Dairy Development Board (NDDB) that gave confidence to the farmers for minimum expected returns. The MSP is the minimum assured price declared every year by the Government of India to pay to the farmers for their produce when the market price fall below the wholesale price. However, still at most of the times, the wholesale prices are much higher (Indian Rs. $40-45 / \mathrm{kg}$ ) than MSP. The MSP is decided based on cost of production and increasing since 2010-2011 (Fig. 7) but there is a need to consider the cost of production based on the production per unit area led by latest technological interventions. The assured procurement of whole quantity of produce is the key for successful implementation of MSP which needs extended infrastructural facilities throughout the country.

Oilseed brassica is grown all over India, however, it dominates in 4 States (Rajasthan, Madhya Pradesh, Haryana and Uttar Pradesh) which contributes $83 \%$ area and $86 \%$ production with a maximum in Rajasthan (46\% area and $48 \%$ production). Eco-regional variations are mainly noted due to biophysical fittingness of the crop. The long-term trends (10 years CAGR from 2004-2005 to 2013-2014) in area is declining in most of the States, however, production and yields have increased (Fig. 8). In Punjab, Rajasthan and Uttar Pradesh area and production showed decreasing trend, whereas, productivity has increasing trend. The concept of eco-regional approach can effectively be utilized to realize potential yields with high inputuse efficiency in these regions. Supporting services like input supply, marketing and processing have to be linked to these ecological zones besides strengthening research and extension systems, and infrastructure facilities. 
Table 2. Crop growing period, yield and per day productivity in major oilseed brassica growing countries.

\begin{tabular}{lllllll}
\hline Country & $\begin{array}{l}\text { Crop duration } \\
(\text { days })\end{array}$ & $\begin{array}{l}\text { Growing period } \\
\text { (calendar months })\end{array}$ & $\begin{array}{l}\text { Photoperiod } \\
(\mathrm{hrs})\end{array}$ & $\begin{array}{l}\text { Yield } \\
(\mathrm{kg} / \mathrm{ha})\end{array}$ & $\begin{array}{l}\text { Yield } \\
(\mathrm{kg} / \mathrm{ha} / \mathrm{day})\end{array}$ & $\begin{array}{l}\text { Yield } \\
(\mathrm{kg} / \mathrm{ha} / \mathrm{photoperiod} \mathrm{hr})\end{array}$ \\
\hline France & $330(90)$ & Aug/Sept-July & 1450 & 3422 & 10.4 & 2.1 \\
Germany & $330(90)$ & Aug/Sept-July & 1416 & 3947 & 11.9 & 2.8 \\
Australia & $150(41)$ & May/June-Nov/Dec & 1315 & 1266 & 8.4 & 1 \\
Poland & $330(90)$ & Aug/Sept-July & 1357 & 2908 & 8.8 & 2.1 \\
Canada & $120(33)$ & May-Aug/Sept & 1206 & 2160 & 18.0 & 1.8 \\
China & $220(60)$ & Sept/Oct-May & 1744 & 1978 & 9.0 & 1.1 \\
India & $140(38)^{\mathrm{a}}$ & Sept/Oct-April & 1663 & 1233 & 8.8 & 0.7 \\
\hline
\end{tabular}

Source for Sunshine hours: https://en.wikipedia.org/wiki/List_of_cities_by_sunshine_duration. Values in parenthesis are the \% time of a year (365 days).

${ }^{\mathrm{a}}$ Growing period for $B$. juncea, rest are B. napus.

Table 3. Comparison of fats available in different oils.

\begin{tabular}{|c|c|c|c|c|c|}
\hline & $\begin{array}{l}\text { Saturated } \\
\text { fatty acid (SFA) }\end{array}$ & $\begin{array}{l}\text { Mono-unsaturated } \\
\text { fatty acid (MUFA) }\end{array}$ & $\begin{array}{l}\text { Linoleic acid } \\
\text { (omega-6 PUFA) }\end{array}$ & $\begin{array}{l}\text { Alpha-linolenic acid } \\
\text { (Omega-3 PUFA) }\end{array}$ & $\begin{array}{l}\mathrm{N}-6 / \mathrm{N}-3 \\
\text { ratio }\end{array}$ \\
\hline Canola & 4 & 62 & 22 & 10 & $2.2: 1$ \\
\hline Soybean & 15 & 27 & 53 & 5 & $10.6: 1$ \\
\hline Peanut & 24 & 50 & 25 & $<0.5$ & $50: 1$ \\
\hline Sunflower & 13 & 27 & 60 & $<0.05$ & $120: 1$ \\
\hline
\end{tabular}

Source: Mishra and Manchanda, 2012.

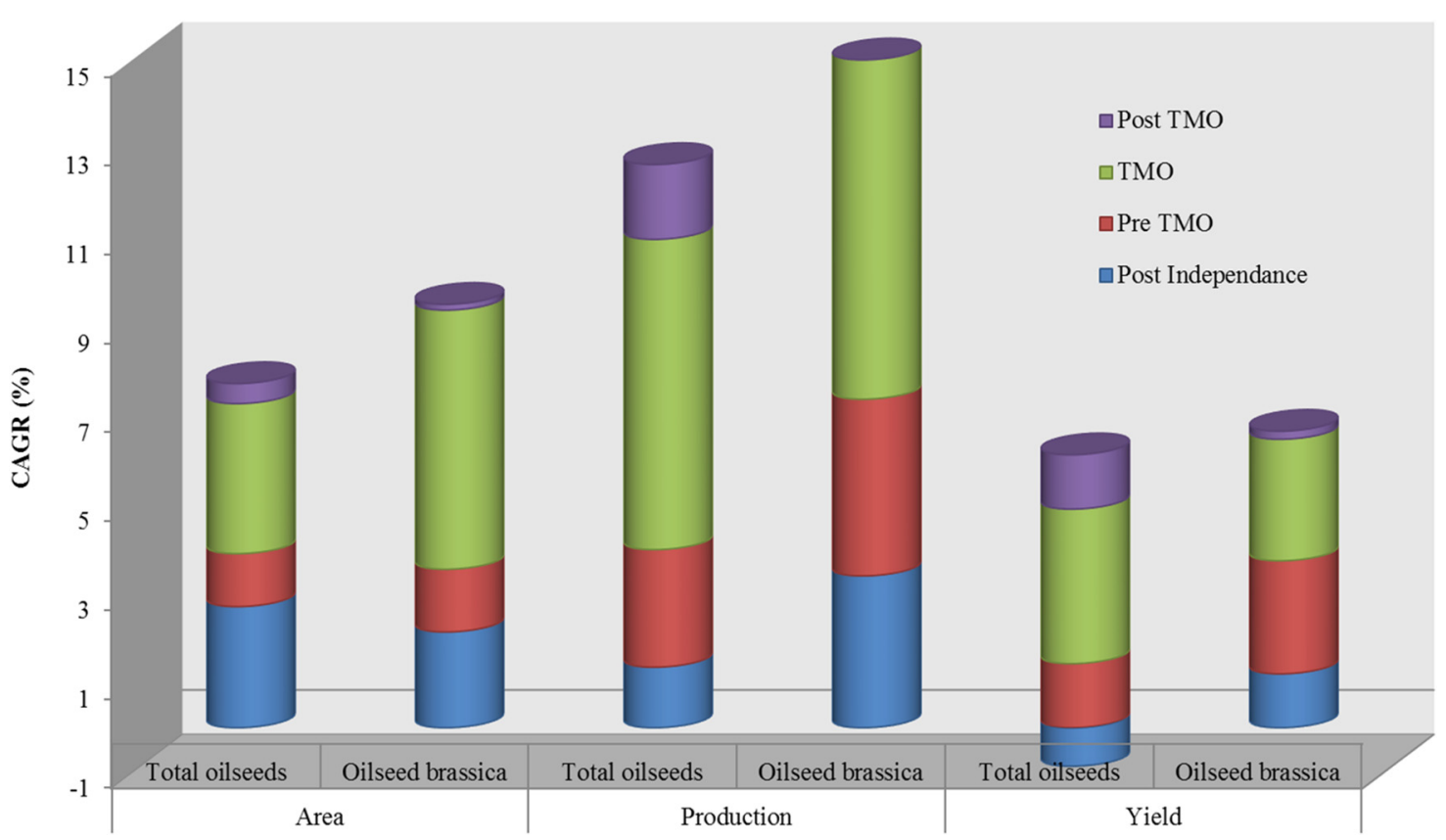

Fig. 6. Growth rate in the area, production and yield of oilseed brassica and total oilseeds during different periods. Source: Agricultural statistics at a glance, Directorate of Economics and Statistics, Ministry of Agriculture, Govt. of India. 


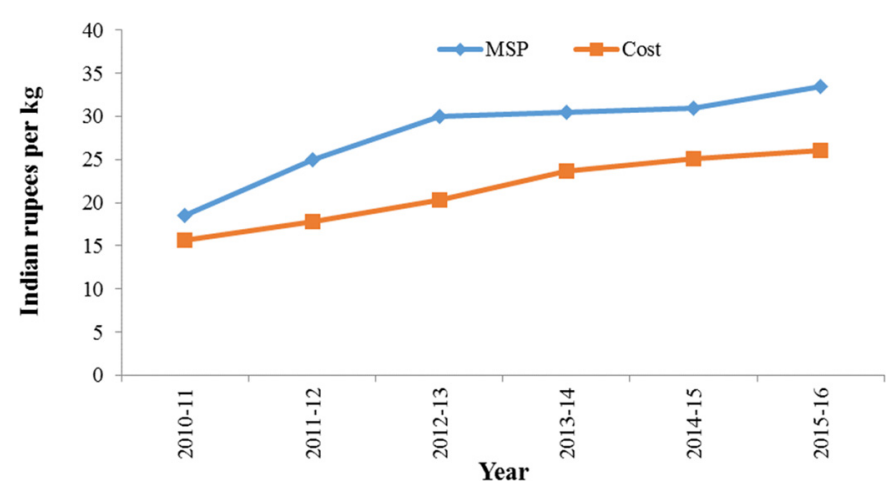

Fig. 7. Minimum support price and cost of production of oilseed brassica. Source: CACP, DAC reports of various years.

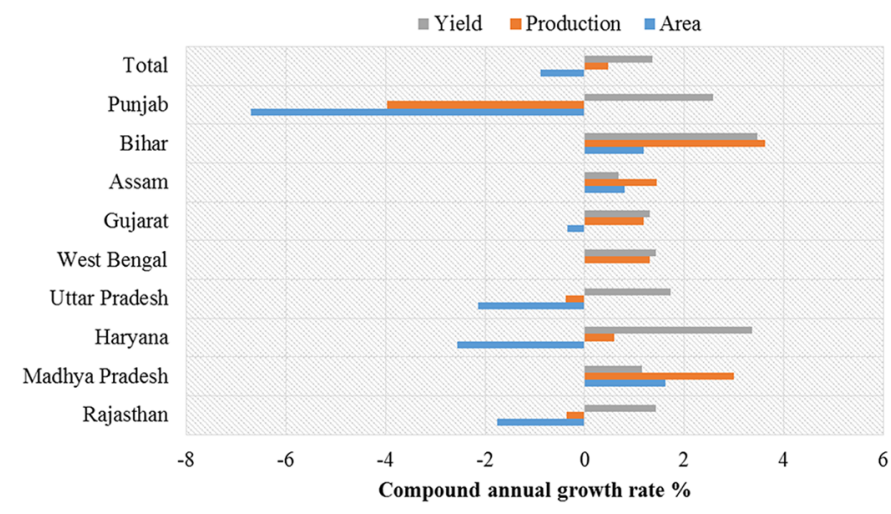

Fig. 8. Growth rate in the area, production and yield of oilseed brassica in major states of India.

\subsection{Oilseed brassica breeding in India}

The varietal development program in India in oilseed brassica was initiated in 1936 when the first strain RT 11 was released for cultivation. Up to 1970 , mass and pure line selection were the main breeding methods used in breeding programmes, and 26 varieties were developed. After 1980, 22 varieties developed through hybridization were released. This number further increased to 41 during the first decade of the 21 st century. Simultaneously, 12 varieties have been developed through mutation breeding. Chauhan and Singh (2004) opined that most of the Indian mustard varieties are the pure line selections derived from a few common ancestors and a limited number of donors was utilized in the breeding programme resulting in a narrow genetic base. Since the early 1980 s, systematic and vigorous recombinant breeding was followed, and a large number of varieties have been identified, and released. The first notified variety was ITSA of toria (B. rapa) in 1973 under the Indian Seed Act 1966. So far, about 189 varieties of oilseed brassica (B. juncea-118, B. carinata-7, B. napus-14, B. rapa var. toria-24, B. rapa var. yellow mustard15, B. rapa- var. brown mustard-3, B. nigra-1, Eruca sativa-7) have been developed and released for different agro-climatic conditions in India. The varieties have also been developed for various traits like tolerant to biotic (white rust, Alternaria blight, powdery mildew) and abiotic stresses (drought, salinity, high temperature and frost), and better quality for specific growing conditions. Various novel genetic stocks of oilseed brassica (low erucic acid, low erucic acid and low glucosinolates, high oil content, high oleic acid and low linolenic acid, dwarf, earliness, long main shoot, bold seed, yellow seed, tetra locular siliquae, white rust resistance, tolerance to high temperature and salinity, and high water use efficiency) were also registered with National Bureau of Plant Genetic Resources (NBPGR), New Delhi for the use in future breeding program.

The major emphasis of varietal improvement program is now on genetic enhancement to widen the genetic basis for seed and oil yield with introgressing traits like; early, timely and late-sown conditions to cater the need of diverse agroecological situations of the country, improvement of oil (low erucic acid) and seed meal (low glucosinolate), high omega oil quality, resistance/tolerance against biotic (white rust, Alternaria blight, Sclerotinia rot diseases, and aphid and painted bug insects) and abiotic stresses (drought, high temperature, frost and salinity).

\subsection{Production of hybrid cultivars}

The availability of heterosis in oilseed brassica has been reported in the early forties (Sun, 1943) and raised the hopes for the Breeders to harness the hybrid vigour and develop hybrids in this crop. Later on in 1968, introgression of cytoplasmic male sterility (CMS) from radish (Raphanus sativus L) using Ogura system to B. juncea have upturned the assurance of hybrid development in oilseed brassica (Banga and Labana, 1984). Systematic efforts for hybrid development in oilseed brassica have started with the CMS systems mainly ogura and tour in B. juncea, and polima in B. napus in 1989. Subsequently, seven new CMS systems viz., siifolia, oxyrrhina, muralis, catholinigra, moricandia and trachystoma were developed till 1995 (Chauhan et al., 2011). The ICARNational Research Centre for Plant Biotechnology, New Delhi, developed fertility restorers for mori and trachy CMS systems. However, it drags some undesirable traits like severe chlorosis and retarded growth in Mori CMS and segregation for fertility/ sterility coupled with crooked siliqua formation in trachy system.

Some other systems were reported like Lyratus, erucoides, canariense and 126-1 and barthauti CMS in oilseed brassica. Three GMS (Genic Male Sterility) lines, viz., YSMS 2, YSMS 6 and YSMS 8163 were found promising to develop hybrids in yellow mustard (B. rapa var. yellow mustard). First commercial hybrid PGSH51 was released by Punjab Agricultural University (PAU), Ludhiana in 1994 and Hyola 401 by Advanta (India) in 1997/2000. Genetic engineering system for the development of male sterility has also been worked out to harness the heterosis in oilseed brassica and to develop barnase-barstar system (Jagannath et al., 2002). In Indian mustard, efforts were concentrated during 1999-2005 on conversion of normal green mori CMS and restorer plants into high-yielding heterotic parents. 


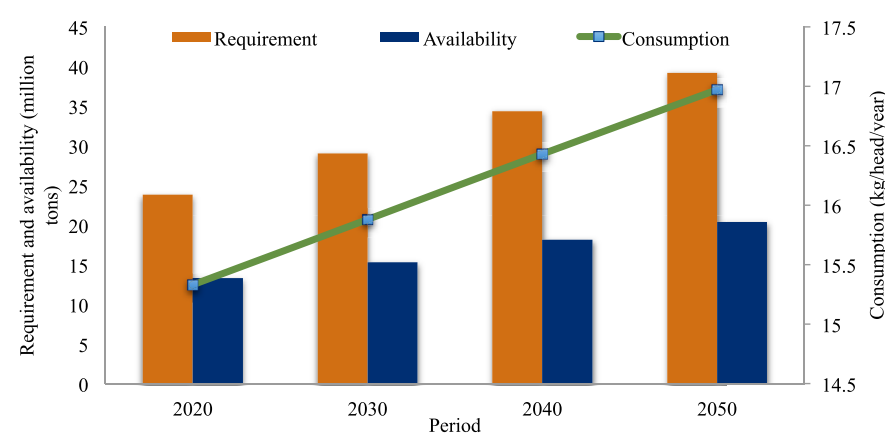

Fig. 9. Projections for demand, availability and per caput consumption of edible oils up to year 2050.

\subsection{Breeding for low glucosinolates and erucic acid content}

Efforts have been made in India since 1970 to breed the varieties of 0 -quality (low either in glucosinolate or erucic acid content) or 00-quality (low in both glucosinolate and erucic acid content) to meet the internationally acceptable standard of oil and seed meal (canola quality). First low erucic acid variety Pusa Karishma of Indian mustard and first double low variety GSC 5 of B. napus were released in 2004 and 2005, respectively. Subsequently, eight 0 -quality varieties (low in erucic acid) have been released in B. juncea and eight 00 -quality varieties (low in erucic and low glucosinolate, Canola quality) have been released in B.juncea (2) and in B. napus (6). Exaggerated current efforts to map the traits for low erucic acid and low glucosinolate content in Indian mustard under the agronomic base of high yield potential are underway.

\section{Future needs and challenges}

India is struggling to reduce edible oils import and increase acreage, and production under the oilseeds, while edible oils requirement is projected to rise to the tune of 20.4 million tonnes in 2020-2021. At the current trends, 39.2 million tons of vegetable oil will be required for the 1.68 billion population in India by half of the 21 st century (Fig. 9) (Anonymous, 2015). To fulfill this requirement, oilseed brassica has to contribute 20.5 million tons of production (assuming a contribution at $25 \%$ in total oilseeds production) by the year 2050 which is a gigantic task for the scientists and policy makers.

To meet out the projected demand of edible oils; area, production and productivity of oilseed brassica should increase at a comparable growth rate. At the present level of contribution of oilseed brassica $(25 \%)$ in total oilseed stock, its area, production and yield have to increase to a tune of 8 million ha, 20.51 million tons and $2563 \mathrm{~kg} / \mathrm{ha}$ by the year 2050 (Fig. 10) (Anonymous, 2015). The present level of the area, production and yield are 6.3 million ha, 7.98 million tons and $1324 \mathrm{~kg} / \mathrm{ha}$, respectively (Table 1). To reach out at the level of projections in the year 2050, the country has to bring 1.7 million ha additional area under plow and double the productivity to produce 3-times more oilseed brassica at the

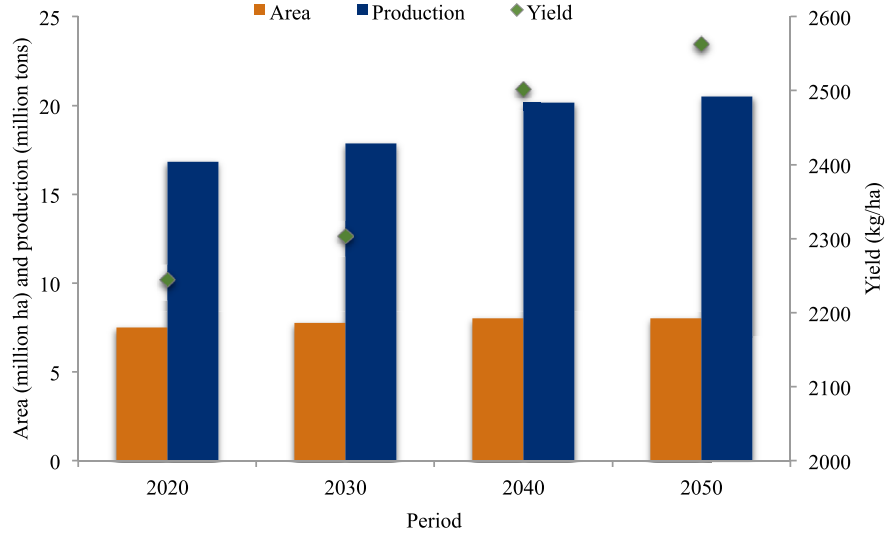

Fig. 10. Projection for the area, production and yield of oilseed brassica up to 2050 .

present figures. Since, the area under plow is almost stagnating in India, additional acreage for oilseed brassica cultivation may possibly be explored in rice-fallow system (North-eastern regions), and in non-traditional areas (southern regions) provided with suitable technology and policy support.

The realization of these targets under the present climate change and variability, degrading finite natural resources (soil and water), and food and nutritional security will be unimaginable without the ground-breaking technological interventions. These challenges are more exacerbated in case of oilseeds where consumption is increasing due to increasing population, changing lifestyle and dietary preferences. To address these challenges, the frontier sciences and technologies should be harnessed and integrated in the ongoing research programs for yield improvement, resource use efficiency, diversified products and uses, stakeholders involvement, and viable supply chain and marketing.

Significant progress has been made in gene pool enhancement and its improvement in India, however, still there is need to develop varieties for diverse agro-ecological situations in traditional and non-traditional areas, input responsive, climate resilient, tolerant to biotic and abiotic stresses, and of high oil content and quality. Application of new breeding approaches from pre-breeding to genetic engineering, marker assisted breeding, heterosis advancement are needed to broaden genetic base and to harness the genotypic potential for high yields equal to or at par with European rapeseed production potential. Science led innovations are required to explore the gene pool for photoperiodic responses and high per day productivity $(\approx 18 \mathrm{~kg} /$ ha/day as in Canada) in B.juncea (at present $8 \mathrm{~kg} / \mathrm{ha} /$ day). Genomics-enabled next generation breeding approaches like gene mining, tagging and tapping tools may help in breaking the yield barriers in $B$. juncea. International collaboration for exchange of material of specific traits of high yield, quality, and insect and disease resistance are to be strengthened to enhance the production of good quality edible oil.

Though, the yield potential of Indian mustard has been realized up to $3.0 \mathrm{t} / \mathrm{ha}$ at experimental fields, however, it failed to perform at farmer field due to input insufficiency (soil and water) or rhizospheric disparities. It suggests the application of 
proven technologies such as integrated nutrient management, precision agriculture and resource conservation approaches for specific agro-ecology. Biotic stresses due to insects, pests and weeds specially Orobanche $(O$. aegyptica) cause yield loss of about $1 / 3 \mathrm{rd}$ in oilseed brassica in different regions of the country. Efforts needed to develop the resistance/tolerant varieties and holistic control measures to reduce the losses.

The mustard oil may be alternatively used for specific highvalue products (low erucic acid or low glucosinolates or both, rich in healthy mineral elements, and medicaments). It is also used for the preparation of margarine which contains unsaturated "good" fats. Apart from the oil, green leaves of oilseed brassica serve an excellent source of CA, Fe, $\mathrm{Mg}, \mathrm{Mn}$, $\mathrm{K}, \mathrm{Zn}$. The oilseed brassica seed meal is a rich source of protein and other phytic and phenolic compounds. It can also be used as polymers, lubricants, plastic, cosmetics, pharmaceuticals, biofumigants and biofuel.

Concerted efforts are needed for the effective dissemination of potential technologies/products. The Farmer-Institution-Industry linkages should be strengthened besides the existing formal delivery mechanisms so that the gap between potentially attainable and realized yield can be bridged. It is obvious that we look forward to mitigating the various kinds of risks and to enhance the production efficiency and profitability. All options for risk mitigation like timely availability of inputs and credit, MSP and procurement, crop insurance, linking farmers to market are needed to put in a place for better oilseed economy. The policy options should also look at the market access not only as edible oil but also as value-added products, animal feed, biodiesel, medicaments, and fortified foods.

\section{Conclusion}

India achieved self-sufficiency in cereals but is still struggling to realize it in oilseeds. The Technology Mission on Oilseeds flagged quantitative jump in the area, production and yield of oilseed brassica in India, however, the same growth rate could not be achieved in the post-TMO period. Projected demand of oilseed brassica oil by $2050 \mathrm{AD}$, represents a 3-fold increase in production and a 2-fold increase in yield, while soil, water, labor, and energy savings have to be achieved. To address the food security in a real sense, a new focus must be given to the oilseed brassica to address the longer-term determinants of nutritional insecurity and hidden hunger. There must be an emphasis on strategies tailored to diverse conditions of agro-ecological, socio-economic and epidemiological situations in oilseed brassica.

\section{Acronyms}

$\begin{array}{ll}\text { CAD } & \text { Coronary artery diseases } \\ \text { CAGR } & \text { Compound annual growth rate } \\ \text { CMS } & \text { Cytoplasmic male sterility } \\ \text { GMS } & \text { Genic male sterility } \\ \text { ICAR } & \text { Indian council of agricultural research } \\ \text { MSP } & \text { Minimum support price } \\ \text { MUFA } & \text { Mono unsaturated fatty acids } \\ \text { NBPGR } & \text { National Bureau of plant genetic resources } \\ \text { NDDB } & \text { National dairy development board } \\ \text { OGL } & \text { Open general license } \\ \text { PAU } & \text { Punjab agricultural university } \\ \text { PUFA } & \text { Poly unsaturated fatty acids } \\ \text { SFA } & \text { Saturated fatty acids } \\ \text { TMO } & \text { Technology mission on oilseeds }\end{array}$

\section{References}

Agricultural statistics at a glance, Directorate of Economics and Statistics, Ministry of Agriculture, Govt. of India. 2017. https:// eands.dacnet.nic.in/.

Anonymous, 2015. Vision 2050, ICAR-Directorate of Rapeseed Mustard Research. www.drmr.res.in/.

Banga SS, Labana KS. 1984. Heterosis in Indian mustard [Brassica juncea (L.) Coss.]. Plant Breeding 92: 61-70.

CACP, DAC. 2016. Commission for agricultural costs and prices. https://cacp.dacnet.nic.in/.

Chauhan JS, Singh KH, Singh VV, Kumar S. 2011. Hundred years of rapeseed-mustard breeding in India: accomplishments and future strategies. Indian J Agric Sci 81(12): 1093-1109.

Directorate of Vanaspati, vegetable oils and fats. 2017. Consumption, net domestic availability and import of edible oils in India. https:// dfpd.nic.in/oil-division.htm.

FAOSTAT, 2016. Food and Agriculture Organization of the United Nations. www.fao.org/faostat/en/.

Jagannath A, Arumugam N, Gupta V, Pradhan A, Verma PK, Pental D. 2002. Development of transgenic barstar lines and identification of a male sterile (barnase) /restorer (barstar) combination for heterosis breeding in Indian oilseed mustard (Brassica juncea). Curr Sci 82: 46-52.

Kumar S. 2015. Edible oils quality and nutraceutical aspects. Stadium Press (India) Pvt. Ltd.: New Delhi.

Mishra S, Manchanda SC. 2012. Cooking oils for heart health. $J$ Prevent Cardiol 1(3): 123-131.

Sun FJ. 1943. Hybrid vigor in Brassica. J Agric Assoc China 175: 35-58.

Cite this article as: Jat RS, Singh VV, Sharma P, Rai PK. 2019. Oilseed brassica in India: Demand, supply, policy perspective and future potential. $O C L$ 26: 8 . 